\title{
Surgery for the acute abdomen in adults with leukaemia
}

\author{
Robert W. Martell and Peter Jacobs \\ University of Cape Town Leukaemia Centre and the Department of Haematology, Groote Schuur Hospital, \\ Observatory, Cape, South Africa.
}

\begin{abstract}
Summary: In a retrospective analysis five of 104 patients with acute leukaemia undergoing cytotoxic chemotherapy developed abdominal signs requiring emergency surgical exploration. Two common features in these patients were the inclusion of cytosine arabinoside in their treatment regimen and a necrotizing lesion involving the terminal ileum, appendix, and right colon. Appendicectomy was performed in two and hemicolectomy in three. Of the patients receiving high-dose cytosine arabinoside one died in the immediate post-operative period and two after recovery from surgery but before marrow regeneration; the remaining two patients received conventional dose cytosine arabinoside, and both recovered. The inclusion of this agent is standard in modern treatment programmes, resulting in significant improvement in longterm disease-free survival, so that a greater awareness of this complication is necessary. Early surgery, utilizing modern support techniques, is recommended as feasible and appears to offer the only realistic chance of survival.
\end{abstract}

\section{Introduction}

The development of an acute surgical abdomen during the pancytopenic period following the administration of cytotoxic chemotherapy for leukaemia is well recognized (Seligman et al., 1972; Steinberg et al., 1973; Sherman \& Woolley, 1973; Rasmussen \& Freeman, 1975; Exelby et al., 1975; Varki et al., 1979; Kies et al., 1979; Lehman \& Armitage, 1980; Yates et al., 1982; Mackinnon et al., 1982; Jones \& Abramson, 1983). In addition to coincidental causes such as acute appendicitis, a specific syndrome of necrotizing enterocolitis has been recognized (Steinberg et al., 1973; Sherman \& Woolley, 1973). In view of the steadily improving results for long-term disease-free survival and possible cure in acute leukaemia (Jacobs \& Gale, 1984; Lister \& Rohatine, 1982), it is important to be aware of this complication, with management centred on early surgical exploration and intensive support which includes an appropriate antibiotic regimen and effective granulocyte and platelet transfusions. Considering the extremely poor prognosis of this syndrome (Steinberg et al., 1973; Sherman \& Woolley, 1973; Yates et al., 1982) and evidence that surgical management offers an alternative option (Rasmussen \& Freeman, 1975; Exelby et al., 1975; Lehman \&

Correspondence: Professor P. Jacobs, M.D., Ph.D., Department of Haematology - Research Centre, University of Cape Town Medical School, Anzio Road, Observatory 7925, Cape, South Africa.

Accepted: 12 May 1986
Armitage, 1980), we present our experience with five such consecutive patients.

\section{Materials and methods}

A retrospective analysis of the case records from 104 consecutive patients with acute leukaemia admitted to the Groote Schuur Hospital, Cape Town, between July 1982 and March 1984 was undertaken. Five patients developed an acute abdomen requiring surgical exploration. These case records were analysed to correlate haematological diagnosis, chemotherapy, and clinical presentation with laparotomy findings and post-operative course.

\section{Results}

The incidence of patients requiring major abdominal surgery in this group was $5 \%$. The clinical and laboratory features are summarized in Table I. There were four males and one female, with a mean age of 33.8 years (range 14-62 years). Three had a diagnosis of acute myeloblastic and two of acute lymphoblastic leukaemia. All were severely neutropenic and thrombocytopenic at the time of presentation with their abdominal symptoms. All had received extensive prior chemotherapy. Patients 1 to 4 had leukaemia refractory to standard induction regimens, while patient 5

(C) The Fellowship of Postgraduate Medicine, 1986

\section{(1)}


Table I Pertinent features of 5 patients who developed abdominal catastrophes

\begin{tabular}{|c|c|c|c|c|c|}
\hline Patient & Age & Sex & Diagnosis & $\begin{array}{c}\text { White cell } \\
\text { count } \times 10^{9} / l\end{array}$ & Blood culture \\
\hline 1 & 62 & $\mathbf{F}$ & Refractory AML* & 0.4 & $\begin{array}{l}\text { Bacillus species } \\
\text { (?contaminant) }\end{array}$ \\
\hline 2 & 50 & $\mathbf{M}$ & Refractory ALL $\dagger$ & 0.1 & $\begin{array}{l}\text { Staphylococcus } \\
\text { epidermidis. Strep- } \\
\text { tococcus bovis. (?con- } \\
\text { taminant) }\end{array}$ \\
\hline 3 & 23 & $\mathbf{M}$ & Refractory AML & 0.4 & Negative \\
\hline 4 & 14 & $\mathbf{M}$ & Refractory ALL & 0.7 & Negative \\
\hline 5 & 20 & $\mathbf{M}$ & $\begin{array}{l}\text { AML in second re- } \\
\text { mission }\end{array}$ & 0.3 & Negative \\
\hline
\end{tabular}

*AML: acute myelocytic leukaemia; ALL: acute lymphoblastic leukaemia.

was in a second remission and receiving consolidation chemotherapy. Blood cultures yielded either negative results or growth of contaminant organisms and were consequently not helpful in guiding the choice of antibiotics.

The details of the acute abdominal presentation are summarized in Table II. All patients had the onset of symptoms within an average of 8 days (range 3-13 days) of commencing chemotherapy. A variety of chemotherapeutic agents were given, but cytosine arabinoside was common to all the programmes. Two patients (Nos. 1 and 5) received conventional doses, while patients 2,3 and 4 received high-dose cytosine arabinoside defined as $3 \mathrm{~g} / \mathrm{m}^{2}$ every 12 hours for 6 days in patient 2 and $2 \mathrm{~g} / \mathrm{m}^{2}$ every 12 hours for 5 days in patients 3 and 4 . The clinical presentation in all patients was that of a surgical abdomen, characterized by acute onset of colicky pain associated with fever and frequently with diarrhoea, which was blood stained in one patient (No.4). Three patients had nausea with vomiting. Abdominal examination revealed signs of peritoneal irritation, generalized in three, but more localized to the right lower quadrant in two. Radiographic findings in two patients were consistent with the presence of a paralytic ileus. Findings at laparotomy (Table II) included nonspecific haemorrhagic or gangrenous bowel in four, with acute appendicitis in one. In three patients the

Table II Features at the time of presentation with signs and symptoms of acute abdomen

\begin{tabular}{|c|c|c|c|c|c|}
\hline Patient & 1 & 2 & 3 & 4 & 5 \\
\hline $\begin{array}{l}\text { Days from } \\
\text { chemotherapy to } \\
\text { symptoms }\end{array}$ & 13 & 9 & 3 & 6 & 8 \\
\hline Chemotherapy & $\begin{array}{c}\text { Cytosine arabinoside } \\
\text { VP16-213 } \\
\text { Adriamycin }\end{array}$ & $\begin{array}{l}\text { High-dose cytosine } \\
\text { arabinoside } \\
\text { m-AMSA }\end{array}$ & $\begin{array}{l}\text { High-dose cytosine } \\
\text { arabinoside }\end{array}$ & $\begin{array}{l}\text { High-dose cytosine } \\
\text { arabinoside }\end{array}$ & $\begin{array}{c}\text { Cytosine-arabin- } \\
\text { oside } \\
\text { VP16-213 } \\
\text { Adriamycin }\end{array}$ \\
\hline $\begin{array}{l}\text { Clinical presenta- } \\
\text { tion }\end{array}$ & $\begin{array}{l}\text { Nausea } \\
\text { Vomiting } \\
\text { Diarrhoea } \\
\text { Peritonitis }\end{array}$ & $\begin{array}{c}\text { Diarrhoea } \\
\text { Right lower } \\
\text { quadrant peritonitis }\end{array}$ & Peritonitis & $\begin{array}{c}\text { Vomiting } \\
\text { Diarrhoea } \\
\text { Haematochezia } \\
\text { Peritonitis }\end{array}$ & $\begin{array}{c}\text { Vomiting } \\
\text { Right lower periton- } \\
\text { itis }\end{array}$ \\
\hline Laparotomy & $\begin{array}{l}\text { Oedematous right } \\
\text { colon and caecum }\end{array}$ & $\begin{array}{l}\text { Gangrenous right } \\
\text { colon and caecum }\end{array}$ & $\begin{array}{l}\text { Gangrenous right } \\
\text { colon and caecum }\end{array}$ & $\begin{array}{c}\text { Haemorrhagic small } \\
\text { bowel }\end{array}$ & $\begin{array}{l}\text { Appendix abscess } \\
\text { Necrotic appendix }\end{array}$ \\
\hline Surgical procedure & $\begin{array}{l}\text { Right hemicolec- } \\
\text { tomy }\end{array}$ & $\begin{array}{l}\text { Right hemicolec- } \\
\text { tomy }\end{array}$ & $\begin{array}{l}\text { Right hemicolec- } \\
\text { tomy }\end{array}$ & Appendicectomy & Appendicectomy \\
\hline Outcome & Recovered & $\begin{array}{l}\text { Died } 10 \text { days post- } \\
\text { operative }\end{array}$ & $\begin{array}{c}\text { Died } 3 \text { days post- } \\
\text { operative }\end{array}$ & $\begin{array}{l}\text { Died } 14 \text { days post- } \\
\text { operative }\end{array}$ & Recovered \\
\hline
\end{tabular}


surgeon performed right hemicolectomy, and in two the appendix was removed. Two patients who received conventional doses of cytosine arabinoside recovered fully simultaneously with marrow regeneration. The three patients who received high-dose cytosine arabinoside died within 2 weeks. Although patients 2 and 4 had recovered from surgery, their deaths were associated with the complications of prolonged marrow aplasia, while patient 3 died shortly after surgery.

\section{Discussion}

The incidence of patients requiring major abdominal surgery in this series is $5 \%$, which approximates closely to that reported by others (Wagner et al., 1970; Steinberg et al., 1973; Exelby et al., 1975; Yates et al., 1982), although the development of an acute abdomen has been reported to occur in as many as $28 \%$ of patients with acute leukaemia (Jones \& Abramson, 1983). The clinical presentation of these five patients was characteristic and included, within several days of receiving chemotherapy, the appearance of fever, vomiting, diarrhoea, gastrointestinal bleeding, abdominal peritonitis, with localization in the right lower quadrant of the abdomen. Radiographic changes are usually not specific (Wagner et al., 1970; Exelby et al., 1975). This syndrome, which has been variously labelled as typhlitis (Wagner et al., 1970; Varki et al., 1979), neutropenic enterocolitis (Kies et al., 1979), the ileocaecal syndrome (Sherman \& Woolley, 1973), and necrotizing enterocolitis (Stein- berg et al. 1973; Yates et al., 1982) should now be sufficiently well characterized, occurring frequently in patients with acute leukaemia who are receiving intensive induction or consolidation chemotherapy during the phase of temporary marrow aplasia with peripheral blood granulocytopenia and thrombocytopenia.

The pathogenesis is not clear, although primary gut necrosis with secondary infection appears to be the likeliest explanation (Leach et al., 1969; Slavin et al., 1978). The reason for the frequent involvement of the caecum and ascending colon is obscure. The syndrome seems to be most frequently associated with the use of cytosine arabinoside and an anthracycline (Yates et al., 1982; Jones \& Abramson, 1983), although it has been reported following a variety of other chemotherapeutic regimens. The present series is remarkable for the association of the syndrome with the prior or concomitant administration of high-dose cytosine arabinoside (Johnson et al., 1985). Prolonged marrow aplasia is a feature of this chemotherapy programme and although two of the patients recovered from the surgery, survival ultimately depends also on the return of peripheral circulating granulocytes and platelets.

The management of this catastrophic complication has been controversial (Johnson et al., 1985), and although recovery without surgical intervention is exceptional (Table III), survival appears to depend on a combination of well planned surgery with recovery of bone marrow function. The role of broad spectrum antibiotics, with platelet and granulocyte transfusions, has contributed significantly to the support of the patient during the post-operative period until marrow

Table III Survival following surgery or nonoperative management for necrotizing enterocolitis

\begin{tabular}{lcccc}
\hline & $\begin{array}{c}\text { Patients } \\
\text { treated } \\
\text { surgically }\end{array}$ & $\begin{array}{c}\text { Outcome } \\
\text { (recovered) }\end{array}$ & $\begin{array}{c}\text { Patients } \\
\text { treated } \\
\text { conservatively }\end{array}$ & $\begin{array}{c}\text { Outcome } \\
\text { (recovered) }\end{array}$ \\
\hline Seligman (1972) & 2 & 1 & - & - \\
Steinberg (1973) & 2 & 0 & 5 & 0 \\
Sherman (1973) & 3 & 1 & 8 & 0 \\
Rasmussen (1975) & 5 & 4 & - & - \\
Exelby (1975) & 9 & 5 & 7 & 0 \\
Slavin (1978) & - & - & - & - \\
Varki (1979) & 1 & 1 & - & - \\
Kies (1979) & 2 & 3 & 11 & - \\
Lehman (1980) & 2 & 2 & - & 1 \\
Yates (1982) & 5 & 5 & 14 & 1 \\
Mackinnon (1982) & - & - & 73 & 2 \\
Jones (1983) & 34 & 24 & & $(3 \%)$ \\
\hline
\end{tabular}


recovery occurs, and is probably the reason for the increasing proportion of patients who survive and recover from surgery (Table III).

\section{Conclusions}

Five patients who developed an acute surgical abdomen while receiving chemotherapy for acute leukaemia are reported. The syndrome of necrotizing colitis is characterized, and its association with the use of high-dose cytosine arabinoside has been noted.

An approach to management utilizing modern supportive facilities together with surgical interven-

\section{References}

EXELBY, P.R., GHANDCHI, A., LANSIGAN, N. \& SCHWARTZ, I. (1975). Management of the acute abdomen in children with leukemia. Cancer, 35, 826.

JACOBS, A.D. \& GALE, R.P. (1984). Recent advances in the biology and treatment of acute lymphoblastic leukemia in adults. New England Journal of Medicine, 311, 1219.

JOHNSON, H., SMITH, T. \& DESFORGES, J. (1985). Cytosinearabinoside-induced colitis and peritonitis; nonoperative management. Journal of Clinical Oncology, 3, 607.

JONES, G.T. \& ABRAMSON, N. (1983). Gastrointestinal necrosis in acute leukemia: a complication of induction therapy. Cancer Investigation, 1, 315.

KIES, M.S., LUEDKE, D.W., BOYD, J.F. \& MCCUE, M.J. (1979). Neutropenic enterocolitis. Cancer, 43, 730.

LEACH, W.B., LASTER, W.R., MAYO, J.G., GRISWOLD, D.P. \& SCHABEL, F.M. (1969). Toxicity studies in mice treated with 1- $\beta$-arabinofuraonsylcytosine (ara-C). Cancer $R e-$ search, 29, 529.

LEHMAN, J.A. \& ARMITAGE, J.O. (1980). Surgical intervention in complications of acute leukemia. Postgraduate Medicine, 68, 89.

LISTER, T.A. \& ROHATINE, A.Z.S. (1982). The treatment of acute myelogenous leukemia in adults. Seminars in Hematology, 19, 172.

MACKINNON, A.E., HANN, I.M. \& MORRIS-JONES, P. (1982). Childhood leukaemia and surgery. British Journal of Surgery, 69, 731.

RASMUSSEN, B.L. \& FREEMAN, J.S. (1975). Major surgery in leukemia. American Journal of Surgery, 130, 647. tion appears to offer the only chance of survival. This attitude is considered worthwhile in view of the improved long-term outlook in patients with acute leukaemia, many of whom may now be cured.

\section{Acknowledgements}

Supported by the University of Cape Town Leukaemia Centre and Staff Research Fund, the Medical Research Council and the National Cancer Association. We thank Jackie Davies for typing and Dr H.-R. Sanders, Chief Medical Superintendent of Groote Schuur Hospital, for permission to publish.

SELIGMAN, B.R., ROSNER, F. \& RITZ, N.D. (1972). Major surgery in patients with acute leukemia. American Journal of Surgery, 124, 629.

SHERMAN, N.J. \& WOOLLEY, M.M. (1973). The ileocecal syndrome in acute childhood leukemia. Archives of Surgery, $107,39$.

SLAVIN, R.E., DIAS, M.A. \& SARAL, R. (1978). Cytosine arabinoside induced gastrointestinal toxic alterations in sequential chemotherapeutic protocols. A clinical-pathologic study of 33 patients. Cancer, 42, 1747.

STEINBERG, D., GOLD, J. \& BRODIN, A. (1973). Necrotizing enterocolitis in leukemia. Archives of Internal Medicine, 131, 538.

VARKI, A.P., ARMITAGE, J.D. \& FEAGLER, J.R. (1979). Typhlitis in acute leukemia. Cancer, 43, 695.

WAGNER, M.L., ROSENBERG, H.S., FERNBACH, D.J. \& SINGLETON, E.B. (1970). Typhlitis: a complication of leukemia in childhood. American Journal of Roentgenology, 109, 341.

YATES, J., GLIDEWELL, O., WIERNIK, P., COOPER, M.R., STEINBERG, D., DOSIK, H., LEVY, R., HOAGLAND, C., HENRY, P., GOTTLIEB, A., CORNELL, C., BERENBERG, J., HUTCHISON, J.L., RAICH, P., NIZZSEN, N., ELLISON, R.R., FRELICK, R., JAMES, G.W., FALKSON, G., SILVER, R.T., HAURANI, G., GREEN, M., HENDERSON, E., LEONE, L. \& HOLAND, J.F. (1982). Cytosine arabinoside with daunorubicin or adriamycin for therapy of acute myelocytic leukemia: a CALGB study. Blood, 60, 454. 